\title{
Kemampuan Pemahaman Matematis Siswa dengan Menggunakan Cabri 3D
}

\author{
Bayu Jaya Tama*, Sri Rezeki, Rezkiyana Hikmah \\ Teknik Informatika, Universitas Indraprasta PGRI, Indonesia \\ *bayujaya88@gmail.com
}

\begin{tabular}{ll}
\hline Article Info & Abstract \\
\cline { 2 - 2 } $\begin{array}{l}\text { Received } \\
22 \text { April } 2020\end{array}$ & $\begin{array}{l}\text { The purpose of this study was to determine differences in students' } \\
\text { mathematical understanding abilities between those using Cabri } 3 D\end{array}$ \\
Revised & experimental research. The sample of the research was grade VIII \\
29 April 2020 & students of one junior high school in Cibinong. The research \\
instrument used was pretest and posttest. Research data were \\
Accepted & analyzed using t-test. The results of this study indicate that the \\
30 April 2020 & mathematical understanding ability of students who learn with $3 D$ \\
cabri media is better than students who study with ordinary learning.
\end{tabular}

Keywords

3D Cabri

Mathematical

Software

Understanding Ability

Copyright $\odot 2020$ by authors, all rights reserved. Authors agree that this article remains permanently open access under the terms of the Creative Commons Attribution License 4.0 International License

How to Cite:

Tama, B. J., Rezeki, S., \& Hikmah, R. (2020). Kemampuan Pemahaman Matematis Siswa dengan Menggunakan Cabri 3D. Journal of Instructional Mathematics, 1(1), $38-43$.

\section{PENDAHULUAN}

Berdasarkan UU Nomor 20 Tahun 2003 pendidikan nasional berfungsi mengembangkan kemampuan dan membentuk watak serta peradaban bangsa yang bermartabat dalam rangka mencerdaskan kehidupan bangsa, bertujuan untuk berkembangnya potensi peserta didik agar menjadi manusia yang beriman dan bertakwa kepada Tuhan Yang Maha Esa, berakhlak mulia, sehat, berilmu, cakap, kreatif, mandiri, dan menjadi warga yang demokratis serta bertanggung jawab. Untuk mewujudkan fungsi pendidikan nasional maka pendidik perlu mengembangkan dan meningkatkan kemampuan para peserta didik. Khususnya pada mata pelajaran matematika, menurut NCTM (2000) ada beberapa kemampuan matematik yang harus dikembangkan oleh pendidik pada saat pembelajaran, diantaranya kemampuan pemahaman, komunikasi, representasi, pemecahan masalah dan koneksi. Untuk mengembangkan dan meningkatkan kemampuan matematik siswa, tentunya para pendidik perlu melakukan inovasiinovasi dalam proses pembelajaran. Misalnya dengan memanfaatkan teknologi. Untuk mata pelajaran matematika, para pendidik bisa memanfaatkan softwaresoftware matematika yang sudah ada dalam proses pembelajaran. Banyak 
software-software matematika yang dapat dimanfaatkan guru saat proses pembelajaran, misalnya cabri 2D, cabri 3D, GeoGebra, skachtpad, maple, dan lainlain. Dengan menggunakan bantuan software-software matematika tersebut dapat membantu mengembangkan dan meningkatkan kemampuan matematik siswa.

Berdasarkan hasil observasi dan wawancara di sekolah dengan salah seorang guru, masih kurangnya pemahaman matematis siswa pada saat pembelajaran, khususnya pada materi geometri. Hal tersebut dikarenakan materi geometri memiliki materi yang mengikutsertakan daya imajinasi siswa dalam belajar, khususnya materi bangun ruang 3D. Lebih lanjut, dalam proses pembelajaran sebagian guru juga masih menggunakan papan tulis dan buku cetak matematika dalam menjelaskan materi (Rezeki, Tama \& Hikmah, 2019), dan selanjutnya guru memberikan tugas kepada siswa. Hal ini membuat pembelajaran di kelas menjadi monoton dan kurang menarik oleh siswa. Oleh karena itu, banyak siswa yang kurang tertarik dan bahkan menganggap materi tersebut sulit. Akibatnya banyak siswa yang kurang memahami konsep dari materi geometri itu sendiri. Hal ini juga sesuai dengan penelitian yang dilakukan oleh Sari (2018) pada tingkat Sekolah Menengah Pertama bahwa kemampuan pemahaman konsep matematis siswa masih rendah, karena masih banyaknya guru yang melakukan proses pembelajaran secara konvensional.

Dengan demikian untuk meningkatkan kemampuan pemahaman matematis siswa tersebut, maka perlu diberikan inovasi pembelajaran dengan memanfaatkan teknologi pembelajaran. Sehingga pembelajaran tersebut menjadi lebih menarik dan siswa pun menjadi lebih tertarik dalam mengikuti pembelajaran (Hikmah, Rezeki \& Tama, 2019). Hal ini sejalan dengan pendapat Akhirni \& Mahmudi (2015) pemanfaatan program-program komputer memungkinkan guru dapat menampilkan materi dengan lebih menarik. Dalam dunia pendidikan telah dikembangkan program pembelajaran matematika untuk membantu menyelesaikan permasalahan geometri khusunya pada bidang ruang yaitu software cabri 3D.

Software cabri 3D memiliki beberapa tools untuk mendesain pembelajaran matematika bangun ruang 3D agar lebih menarik. Selain itu, kesulitan siswa dalam melakukan imajinasi terhadap konsep bangun ruang dapat digiring ke dalam satu pemahaman yang sama, sehingga siswa tidak mengalami gagal paham dengan konsep materi.

Penggunaan software cabri 3D dapat membantu siswa dalam memahami konsep sifat dari setiap bangun ruang yang akan dibahas melalui gambar yang jelas, sehingga siswa dapat memahami konsep tersebut. Contoh sederhana adalah ketika guru hendak menjelaskan bahwa sebuah kubus akan dibuka sehingga akan berubah menjadi sebuah jaring-jaring kubus. Pada saat menjelaskan konsep tersebut, guru biasanya menggunakan media kubus yang terbuat dari karton. Selanjutnya, guru memotong sisi atas kubus dan sisi lainnya sehingga terbentuklah jaring kubus. Metode tersebut sudah jarang digunakan oleh guru lagi karena tidak efisien waktu. Oleh karena itu, beberapa guru terkadang meminta siswa untuk membayangkan sebuah kubus yang dibuka dari sisi atas kubusnya. Hal tersebut membuat beberapa siswa yang bingung dengan pernyataan yang dikemukakan oleh guru. Oleh karena itu, siswa mengalami kesulitan dalam memahami konsep sifat dari setiap bangun ruang. 
Berdasarkan latar belakang masalah yang telah diuraikan di atas, maka peneliti tertarik untuk melakukan penelitian dengan perumusan masalah apakah kemampuan pemahaman matematis siswa dengan menggunakan cabri 3D lebih baik daripada kemampuan pemahaman matematis siswa dengan model pembelajaran biasa.

\section{METODE PENELITIAN}

Populasi pada penelitian ini adalah seluruh siswa semester 2 pada salah satu SMPN di Cibinong, Tahun Pelajaran 2018/2019 dengan materi "Bangun Ruang Sisi Datar". Sampel pada penelitian ini adalah siswa kelas VIII SMPN Cibinong yang memiliki kemampuan heterogen. Teknik pengambilan sampel pada penelitian menggunakan purposive sampling.

Desain penelitian ini menggunakan desain kelompok kontrol non ekuivalen (Ruseffendi, 2005) sebagai berikut.

$$
\begin{array}{lllll}
\text { Kelas Eksperimen } & : & \mathrm{O} & \mathrm{X} & \mathrm{O} \\
\text { Kelas Kontrol } & : & \mathrm{O} & & \mathrm{O}
\end{array}
$$

Keterangan:

$\mathrm{O}$ : Pretes atau Postes

$\mathrm{X}$ : Pembelajaran dengan cabri 3D

--- : Subyek tidak diperoleh secara acak

Pemilihan desain ini dikarenakan kelas yang ada sudah terbentuk sebelumnya sehingga pengelompokan secara acak tidak dilakukan lagi. Apabila pengelompokkan secara acak dilakukan, dimungkinkan akan terjadi ketidakjelasan jadwal untuk semua bidang mata pelajaran dan mengganggu proses serta efektivitas pembelajaran di sekolah.

Penelitian ini menggunakan instrumen tes kemampuan pemahaman matematis pada masing-masing kelas (eksperimen dan kontrol) berupa tes awal (pretest) dan tes akhir (postest) dengan soal yang sama. Pemberian soal yang sama ini dilakukan untuk melihat ada atau tidaknya peningkatan akibat perlakuan sehingga akan lebih baik jika diukur dengan soal yang sama. Data yang diperoleh dari hasil pretes dan postes diolah dengan bantuan software SPSS Versi 16 for Windows.

\section{Uji Prasyarat Analisis}

\section{HASIL DAN PEMBAHASAN}

Uji prasyarat analisis ini meliputi uji normalitas dan uji homogenitas varians yang masing-masing menggunakan uji Kolmogorov-Smirnov dan uji Levene's Test. Hasil analisis tersebut disajikan sebagai berikut.

\section{Uji Normalitas Kemampuan Pemahaman Matematis}

Data kemampuan pemahaman matematis siswa dari dua kelompok pembelajaran telah diperoleh. Data tersebut akan dianalisis distribusinya. Hasil analisis uji normalitas data dapat dilihat pada Tabel 1 berikut. 
Tabel 1. Hasil Uji Normalitas Skor Kemampuan Pemahaman Matematis

\begin{tabular}{|c|c|c|c|c|c|c|}
\hline \multirow{2}{*}{ Kemampuan } & \multirow{2}{*}{ Nilai } & \multirow{2}{*}{ Kelas } & \multicolumn{3}{|c|}{ Uji Kolmogorov-Smirnov } & \multirow{2}{*}{ Ket. } \\
\hline & & & Stat & $d f$ & Sig & \\
\hline \multirow{2}{*}{ Pemahaman } & \multirow{2}{*}{ Postes } & Eksperimen & 0,162 & 25 & 0,088 & Terima $H_{0}$ \\
\hline & & Kontrol & 0,142 & 25 & 0,200 & Terima $H_{0}$ \\
\hline
\end{tabular}

Berdasarkan Tabel 1 dapat dilihat nilai signifikan dari postes di kelas eksperimen dan kelas kontrol masing-masing adalah 0,088 dan 0,200. Hal tersebut menunjukkan bahwa nilai signifikan untuk postes kelas eksperimen lebih tinggi dari $\alpha=0,05$, yang berarti $\mathrm{H}_{\mathrm{o}}$ diterima. Sedangkan nilai signifikan di kelas kontrol juga lebih tinggi dari $\alpha=0,05$, yang berarti $H_{0}$ diterima. Oleh karena itu, data berdistribusi normal. Dengan demikian, data postes kemampuan pemahaman siswa dilanjutkan dengan uji homogen.

\section{Uji Homogenitas Varians Skor Postes Kemampuan Pemahaman Matematis}

Hasil uji homogenitas varians data postes kemampuan pemahaman matematis selengkapnya dapat dilihat pada Tabel 2 berikut.

Tabel 2. Hasil Uji Homogenitas Varians Kemampuan Pemahaman Matematis

\begin{tabular}{cccccc}
\hline \multirow{2}{*}{ Data } & \multicolumn{5}{c}{ Levene's Test } \\
& Levene's Statistic & $d f 1$ & $d f 2$ & Sig & \multirow{2}{*}{ Keterangan } \\
\hline Postes & 3,152 & 1 & 48 & 0,082 & Terima $H_{0}$ \\
\hline
\end{tabular}

Pada Tabel 2 dapat dilihat bahwa nilai Levene's Sig postes dari hasil uji homogenitas varians adalah 0,082. Hal tersebut menunjukkan bahwa nilai Levene's Sig lebih tinggi dari nilai $\alpha=0,05$ sehingga varians skor postes di kelas eksperimen dan kontrol adalah homogen. Oleh karena itu, dapat disimpulkan bahwa $\mathrm{H}_{\mathrm{o}}$ diterima. Dengan demikian, data postes dilanjutkan dengan uji-t.

\section{Uji Hipotesis}

Hasil uji perbedaan dua rerata postes kemampuan pemahaman matematis siswa dapat dilihat pada Tabel 3 berikut.

Tabel 3. Hasil Uji Perbedaan Dua Rerata Postes Kemampuan Pemahaman Matematis Siswa

\begin{tabular}{|c|c|c|c|c|}
\hline \multirow{2}{*}{ Skor } & \multicolumn{3}{|c|}{ t-test for aquality of means } & \multirow{2}{*}{ Keterangan } \\
\hline & $t$ & df Sig. 2-tailed & Sig. 1-tailed & \\
\hline Post & 6,319 & 0,000 & 0,000 & Tolak $\mathrm{H}_{\mathrm{o}}$ \\
\hline
\end{tabular}

Berdasarkan Tabel 3 dapat dilihat bahwa nilai signifikansi satu pihak pada nilai postes kemampuan pemahaman matematis lebih rendah dari nilai $\alpha=0,05$ yaitu 0,000 maka $\mathrm{H}_{\mathrm{o}}$ ditolak. Hal tersebut dapat diartikan bahwa kemampuan pemahaman matematis siswa yang belajar dengan software cabri 3D lebih baik daripada siswa yang belajar dengan pembelajaran biasa.

\section{Pembahasan}

Secara umum pembelajaran matematika menggunakan media cabri 3D telah berjalan dengan baik. Berdasarkan hasil penelitian, siswa yang menggunakan 
pembelajaran dengan media cabri 3D ini lebih baik dibandingkan dengan siswa yang tidak menggunakan media cabri 3D saat pembelajaran.

Hasil analisis statistik data hasil tes kemampuan pemahaman matematis siswa pada materi bangun ruang menunjukkan bahwa rata-rata hasil tes kemampuan pemahaman matematis siswa dengan menggunakan Cabri 3D lebih baik daripada rata-rata hasil tes kemampuan pemahaman matematis siswa dengan model pembelajaran biasa. Kondisi tersebut tidak terlepas dari penggunaan software cabri 3D dalam proses pembelajaran. Menurut Accascina \& Rogora (2005), Cabri 3D adalah software yang sangat berguna untuk mengajar geometri tiga dimensi. Software ini bersifat dinamis dari diagram digital yang membantu siswa dalam mengembangkan konsep geometri. Software Cabri 3D membantu siswa dalam mengonstruksi bangun ruang dengan langkah-langkah konstruksi yang telah disiapkan. Ariani, Rahmah \& Mawran (2019) penggunaan software Cabri 3D dalam proses pembelajaran geometri yang objek kajiannya bersifat abstrak mempunyai peranan penting bagi siswa, karena dapat memberikan cara baru bagi siswa dan guru dalam mempresentasikan konsep secara kompleks dan dapat memanipulasi objek-objek yang abstrak dengan tangannya sendiri. Jadi, dengan penggunaan software cabri 3D secara tidak langsung membuat siswa menjadi lebih aktif dalam pembelajaran, sehingga dapat berpengaruh terhadap kemampuan pemahaman matematis siswa tersebut.

Berdasarkan hasil penelitian Akhirni \& Mahmudi (2015) pembelajaran dengan memanfaatkan program Cabri 3D berpengaruh secara signifikan terhadap hasil belajar dan motivasi belajar siswa. Sumliyah (2019) hasil penelitian yang telah dilakukan menunjukkan bahwa terdapat efektivitas kemampuan pemahaman konsep matematis siswa dengan menggunakan software cabri 3D. Dengan demikian, pembelajaran matematika dengan menggunakan software cabri 3D ini dapat dijadikan salah satu bentuk variasi media pembelajaran yang dapat digunakan guru dalam menyampaikan konsep materi bangun ruang.

\section{KESIMPULAN}

Berdasarkan uraian dan penjelasan pada hasil penelitian dan pembahasan sebelumnya, kesimpulan penelitian yang dapat dikemukakan adalah kemampuan pemahaman matematis siswa yang belajar dengan software cabri 3D lebih baik daripada siswa yang belajar dengan pembelajaran biasa. Jadi, dengan penggunaan software cabri 3D secara tidak langsung membuat siswa menjadi lebih aktif dalam pembelajaran, sehingga dapat berpengaruh terhadap kemampuan pemahaman matemtis siswa tersebut.

\section{REFERENSI}

Accascina, G., \& Rogora, E. (2005). Using Cabri 3D Diagrams For Teaching Geometry. International Journal for Technology in Mathematics Education, 13(1), 79-87

Akhirni, A., \& Mahmudi, A. (2015). Pengaruh Pemanfaatan Cabri 3D dan Geogebra pada Pembelajaran Geometri Ditinjau dari Hasil Belajar dan motivasi. Jurnal Pendidikan Matematika dan Sains, 3(2) 91-100. https:// doi.org/10.21831/jpms.v6i2.10922 
Ariani, Y., Rahmah, J., \& Mawran M. (2019). Penggunaan software Cabri 3D untuk Meningkatkan Kemampuan Spasial Siswa Sekolah Menengah Pertama. Jurnal Peluang, 7(2), 11-21. http://doi.org/10.24815/jp.v7i2.13695

Hikmah, R., Rezeki, S., \& Tama, B. J. (2019). Penggunaan Cabri 3D terhadap Peningkatan Kemampuan Representasi Matematis Siswa. SAP (Susunan Artikel Pendidikan), 4(2), 163-170.

Kementerian Pendidikan dan Kebudayaan. (2003). Undang-undang No. 20 Tahun 2003 Tentang Sistem Pendidikan Nasional. www.shorturl.at/kMNX4

National Council of Teacher of Mathematics. (2000). Principles and Standards for School Mathematics. Reston, VA: NCTM

Priatna, N. (2017). Students' Spatial Ability through Open-Ended Approach Aided by Cabri 3D. Journal of Physics: Conference Series, 895(1), 012065. http://doi.org/10.1088/1742-6596/895/1/012065

Rezeki, S., Tama, B. J., \& Hikmah, R. (2019). Meningkatkan Kemampuan Pemahaman Matematis Siswa melalui Penggunaan Cabri 3D. In Prosiding Seminar Nasional Pendidikan STKIP Kusuma Negara, 1-4.

Ruseffendi, E. T. (2005). Dasar-Dasar Penelitian Pendidikan dan Bidang NonEksakta Lainnya. Bandung: Tarsito.

Sari, D. P. (2018). Pengaruh Model Pembelajaran Tipe Numbered Heads Togheter terhadap Kemampuan Pemahaman Konsep Matematika. Jurnal Mathematic Pedagogic, 2(2), 196-203. https://doi.org/10.36294/jmp.v2i2.220

Sumliyah, S. (2019). Penerapan Media Pembelajaran Cabri 3D pada Kemampuan Pemahaman Konsep Matematika SMK Materi Bangun Ruang. Integral, 10(1), 16-27, https://doi.org/10.32534/jnr.v10i1.637 